\title{
Systematics and faunistics of Neotropical Euliina, 3: Proathorybia RAZOWSKI, 1997 and related genera (Lepidoptera, Tortricidae, Cochylini)
}

\author{
JÓZEF RAZOWSKI $^{1 *}$, VITOR O. BECKER ${ }^{2}$ \\ ${ }^{1}$ Institute of Systematics and Evolution of Animals, PAS, ul. Sławkowska 17, \\ 31-016 Kraków, Poland \\ ${ }^{2}$ Reserve Serra Bonita, PO Box 01, 45880-970 Camacan, BA, Brazil
}

\begin{abstract}
The euliine genera Sagittranstilla RAZOwSKI \& BeCKER, 1999 and Proathorybia RAZOwsKI, 1997 are discussed. Teapeulia gen. n., Thypsaenia gen. n., Thypsaenia psaenythia sp. n., Sagittranstilla oios sp. n., Teapeulia banhadana sp. n., Teapeulia sepulturae sp. n. and Teapeulia albicota sp. n. are described as new. The new combinations Tortrix minima WALSINGHAM, 1914 and Proathorybia unisignata RAZOWSKI \& PELZ, 2003 are transferred to Teapeulia. Proathorybia chlidonias RAzOWSKI, 1999, Proathorybia meyi RAzOWSKI, 2001 are transferred to Teapeulia and Sagittranstilla, respectively. An adult of Proathorybia zonalis RAZOWSKI \& BECKER, 2000 is illustrated.
\end{abstract}

KEY WORDS: Tortricidae, Tortricinae, Cochylini: Euliina, new genera, new species, Neotropics, Brazil.

\section{INTRODUCTION}

The present, sixth paper in our series on the Neotropical Euliina deals with Sagittranstilla RAZOWSKI \& BECKER, 1997, Proathorybia RAZOWSKI, 1999, Teapeulia gen. n., and Thypsaenia gen. $\mathrm{n}$.

The first two genera were diagnosed by RAZOWSKI (2016).

\footnotetext{
*Corresponding author: razowski@isez.pan.krakow.pl
} 


\section{MATERIAL}

The specimens examined for this paper were collected by the second author. The types of the newly described species are deposited in the BECKER collection, Camacan, Brazil, and will eventually be deposited in one of the major Brazilian Museums.

The numbers cited on the labels of the specimens are the entry numbers in the register book of the second author.

Abbreviations: GS - genitalia slide, WZ - Witold ZAJDA.

\section{RESULTS}

\section{Sagittranstilla RAZOWSKI \& BECKER, 1999}

Sagittranstilla RAZOwsKi \& BeCKer, 1999, Polskie Pismo entomol., 68 (4): 410. Typespecies: Sagittranstilla mageana RAZOWSKI \& BECKER, 1999.

\section{Biology and distribution}

Sagittranstilla is known from three Brazilian states - Minas Gerais, Rio de Janeiro and Santa Catarina - and was collected in January and August at altitudes from 150 to $1300 \mathrm{~m}$, in Rio de Janeiro and Minas Gerais, respectively.

\section{Remarks}

Sagittranstilla was described as a monotypic genus to include the Brazilian S. mageana RAZOWSKI \& BECKER, 1999. Chiefly on the basis of the male genitalia characters, we transfer Proathorybia meyi RAZOWSKI, 2001, comb. n. to Sagittranstilla. Proathorybia meyi is the only species of the genus in which both sexes are known.

\section{Sagittranstilla mageana RAZOWSKI \& BECKER, 1999}

\section{Distribution}

S. mageana was described from one male collected in Rio de Janeiro at an altitude of 400 $\mathrm{m}$. Another male was collected in Marngaritiba, in the same state at $150 \mathrm{~m}$, also in January. 


\section{Sagittranstilla oios sp. n.}

(Figs 1, 2, 13)

S. oios is related to $S$. mageana but differs from it chiefly by the thorny, terminally broad sacculus and the five slender, basally fused cornuti.

\section{Description}

Wing span $15 \mathrm{~mm}$. Head and thorax brown. Forewing in postmedian half uniformly broad; costa curved outwards basally, straight postmedially; termen slightly oblique, straight. Ground colour pale yellow-brown, sprinkled brown, with brown remnants of basal blotch chiefly on dorsum. Distal half of wing tinged brown-grey; costal half of median fascia brown, remaining parts ill-defined, much paler; subapical blotch triangular, elongate distally, not reaching apex of wing; terminal marking slender, terminating at mid-termen (atrophied in left wing). Cilia brown-yellow, brown at apex. Hindwing whitish cream in distal part strigulated brownish grey; cilia whitish.

Male genitalia (Figs 1, 2). Uncus slender, constricted in basal third, slightly tapering terminad, rounded apically; socius proportionally large, broadening and rounded terminally; gnathos arms slender; dorsobasal part of costa of valva long, upcurved, median part slightly convex, tapering apicad; sacculus reaching to beyond mid-valva, gently concave postbasally, broadening, spiny terminally; transtilla a simple band narrowing slightly medially; juxta with median process; phallus moderately broad; caulis very short; cornuti five slender basally fused spines forming a basal plate.

Female unknown.

\section{Type material}

Holotype male: "Brasil: M[inas]G[erais], Caraca 1300 m, 7-10.V. 1996, V.O. BECKER Col; Col. BECKER 108177”; GS 343 WZ.

\section{Etymology}

The name relates to the systematic position of the species: Greek oios - solitary. 

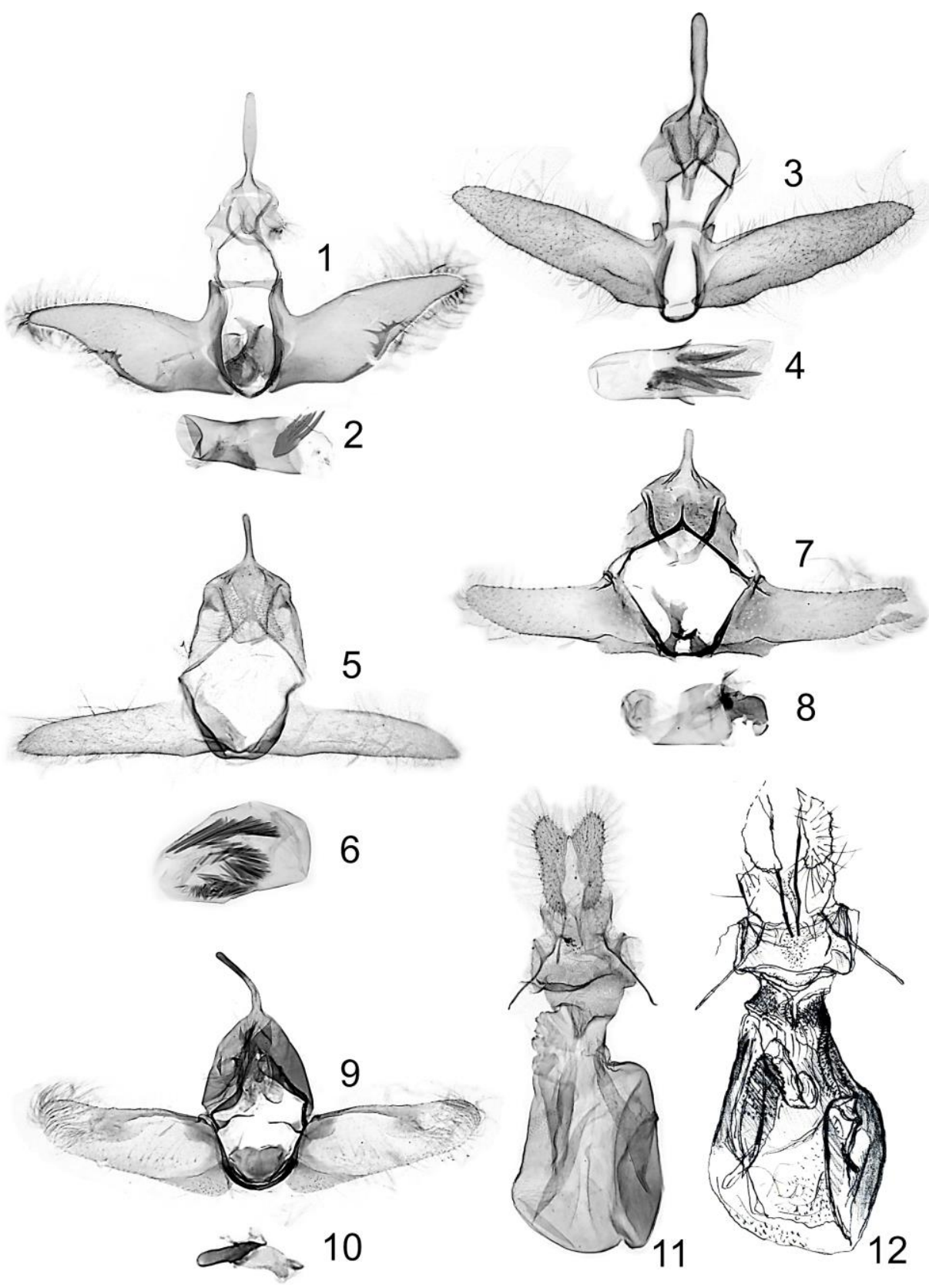

Figs 1-12. Male and female genitalia: 1, 2 - Sagittranstilla oios sp. n., holotype, 3, 4 - Teapeulia banhadana sp. n., holotype, 5, 6-T. sepulturae sp. n., holotype, 7, $8-T$. albicota sp. n., holotype, 9, 10 - Thypsaenia psaenythia sp. n., holotype, 11 - Teapeulia sepulturae sp. n., paratype, 12 - Teapeulia sp., Sinaloa, Mexico, GS 12017. 

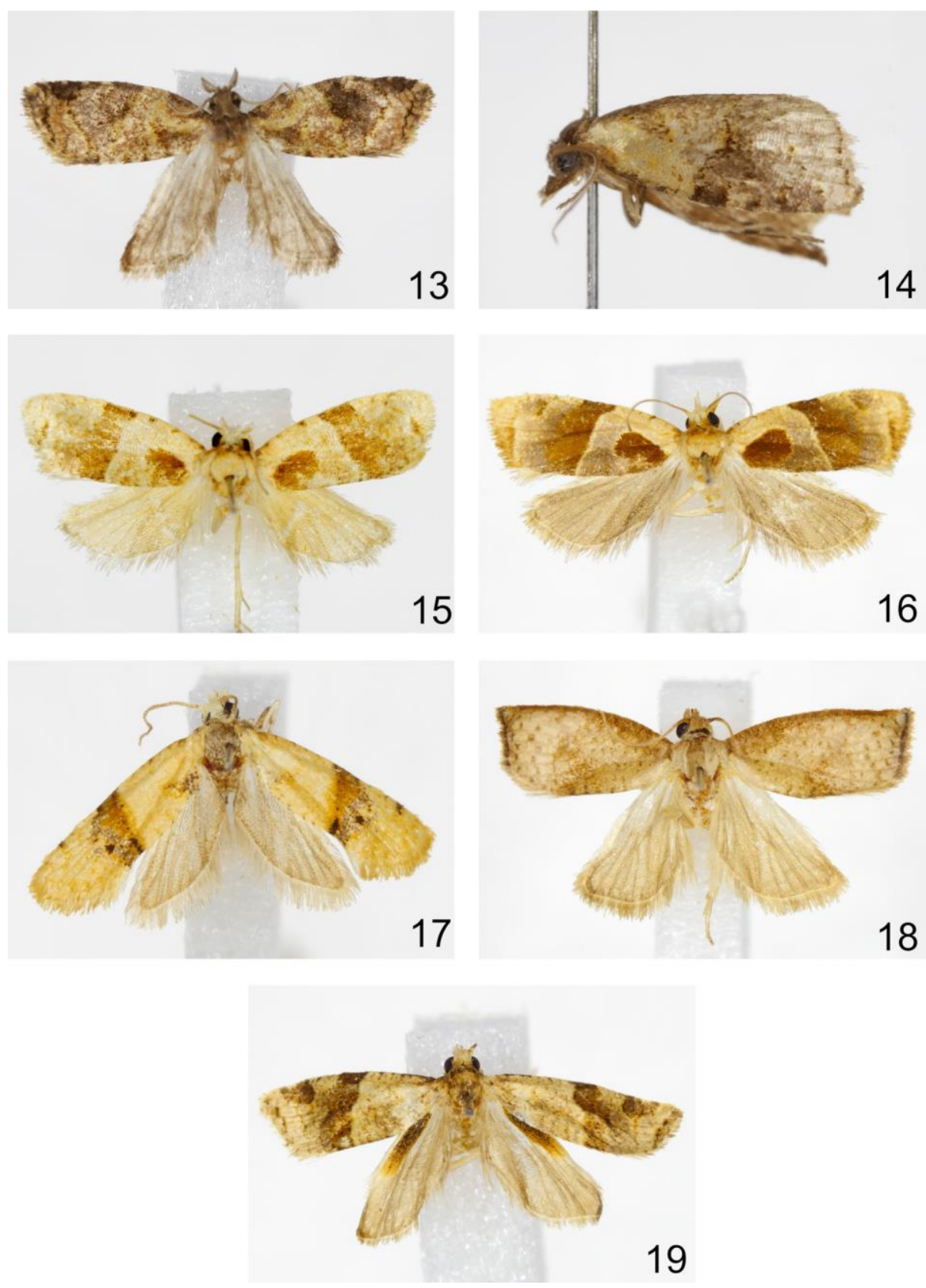

Figs 13-19. Adults: 13 - Sagittranstilla oios sp. n., holotype, 14 - Teapeulia banhadana sp. n., holotype, $15-T$. sepulturae sp. n., holotype, $16-T$. sepulturae sp. n., paratype, $17-T$. albicota sp. n., holotype, 18 - Thypsaenia psaenythia sp. n., holotype, 19 - Proathorybia zonalis RAZOWSKI \& BECKER, 2000, Chapada, Linares, Brazil. 


\section{Teapeulia gen. $\mathbf{n}$.}

(Fig. 12)

Type species: Tortrix minima WALSINGHAM, 1914.

\section{Diagnosis}

In facies, Teapeulia is similar to Proathorybia, especially in the forewing pattern, but Teapeulia has a well-developed dorsobasal blotch. The male genitalia of Teapeulia are distinguished chiefly by the atrophied transtilla, the elongate base of the valval costa, and the long terminal plate of the gnathos.

\section{Description}

Wing span $8-13 \mathrm{~mm}$. Forewing markings include dorsopostbasal blotch, median fascia usually diffuse posteriorly, subapical blotch, and ill-defined terminal marking.

Male genitalia. Tegumen moderately long; uncus simple, slender; socii large, drooping, submembranous; gnathos arm slender, terminal plate small; valva elongate with welldeveloped, usually straight costa; sacculus straight, simple or with indistinct postbasal angulation; transtilla membranous or with weakly sclerotized edge; juxta a simple plate; phallus usually broad, tapering terminally; coecum penis broad, rounded; cornuti - numerous noncapitate small spines forming one to four groups of small or moderate spines, if present.

Female genitalia. Ovipositor and apophyses short; sterigma broad, short, with short anteostial part; ductus bursae fairly short, broad, mostly membranous or with sclerites and spinules; corpus bursae elongate-oval with large sclerites and/or groups of spinules.

\section{Etymology}

The name refers to the type locality of T. minima, Teapa (Tabasco, Mexico) and the generic name Eulia HÜBNER, 1825.

\section{Biology}

Nothing is known about the biology except for the collection dates of the moths: March to May, July - August and October at altitudes of $400-1700 \mathrm{~m}$.

\section{Distribution}

Known from Mexico (Tabasco, Sinaloa, Veracruz, Chiapas) and Costa Rica (Puntarenas) to Ecuador and Brazil (Bahia, Mato Grosso, Curitiba). 


\section{Remarks}

Two species are known to date - the Mexican Teapeulia minima (WALSINGHAM, 1914) comb. n. described in Tortrix, Teapeulia chlidonias (RAZOWSKI, 1999) - comb. n.; and Teapeulia unisignata (RAzOWSKI \& PelZ, 2003) - comb. n. - both from Ecuador and described in Proathorybia RAZOWSKI, 1999. The female genitalia were hitherto unknown. Now, we have examined two females, differing distinctly from one another. One, from Sinaloa, Mexico (Fig. 12), is similar to Teapeulia minima both in facies and male genitalia, while the other is described here as T. sepulturae (Fig. 11). The Teapeulia species from various Mexican localities show slight differences in the male genitalia but their females are probably more easily identified, as one can judge from Figs. 11 and 12.

\section{Teapeulia banhadana sp. $\mathbf{n}$.}

(Figs 3, 4, 14)

\section{Diagnosis}

T. banhadana is related to T. sepulturae from which it differs by its grey forewing ground colour and the presence of a greyish brown triangular costal blotch, and, in the male genitalia, chiefly by the long uncus and the series of large cornuti.

\section{Description}

Wing span $14 \mathrm{~mm}$. Head and thorax dark greyish brown. Forewing expanding weakly terminad; costa straight to middle, then slightly bent; termen long, concave beneath apex, indistinctly convex postmedially. Ground colour greyish white with grey-brown admixture and sparse, slightly darker strigulation. Markings brownish; basal blotch well developed at costa; median fascia brown at costa grey towards median cell, atrophying in dorsal half of wing, subapical blotch small; a few brown spots along costa; termen edged brownish. Cilia (remnants) brownish. Hindwing brownish cream.

Male genitalia (Figs 3, 4). Uncus long, uniformly broad except for slender base; socius large, broad, rounded apically; arm of gnathos slender, terminal plate elongate; valva mostly slender, tapering slightly terminad, pointed apically; sacculus simple, broad basally, weakly angulate; transtilla a simple, short band; phallus moderately broad; cornuti seven mostly strong spines.

\section{Etymology}

The name refers to the type locality, Banhado. 


\section{Material examined}

Holotype male: 'Banhado, Quatro Barras, Parana', Brasil - 800 m, 28. XII. 1970, BECKER \& LAROCA; Col. BECKER 34564”, GS 35254 MK.

\section{Teapeulia sepulturae $\mathbf{s p .} \mathbf{n}$.}

(Figs 5, 6, 11, 15, 16)

\section{Diagnosis}

$T$. sepulturae is closely related to $T$. minima but differs from it by the slender, curved socii, the slender dorsally convex valva and terminally protruding ventral edge, the slightly angulate sacculus, and numerous variably sized cornuti which are absent in minima. The Ecuadoran $T$. chlidonias RAZOWSKI, 1999 also lacks the cornuti but differs from T. sepulturae chiefly by the shorter phallus, broad basal part of the valva and broad socii.

\section{Description}

Wing span $11 \mathrm{~mm}$. Head and thorax white-cream, latter tinged brown proximally. Forewing expanding slightly terminad; costa gradually curved outwards; termen moderately oblique, straight. Ground colour white-cream. Markings brownish consisting of dorsobasal blotch, darker median fascia expanding dorsally, with straight proximal edge, and weak terminal marking. Cilia (worn) white-cream, brownish at tornus. Hindwing creamish tinged brown in anal area; cilia whitish.

Female wing span $12.5 \mathrm{~mm}$. Head white-cream, vertex and lateral part of labial palpus except for third joint, which is brownish. Ground colour suffused grey except for costal and terminal parts of wing; markings of basal and median part of wing dark brown edged cream; subapical and terminal markings pale brown. Cilia concolorous with ground colour. Hindwing pale grey-brown; cilia cream tinged yellow at apex.

Male genitalia (Figs 5, 6). Uncus slender, shorter than socius; the latter slender, curved near middle, slender in terminal part; arm of gnathos slender; valva slender, weakly broadening basally with costa slightly convex, bent subterminally; sacculus slender with indistinct angulation; transtilla membranous; phallus short, broad; coecum penis short; cornuti numerous variably long spines forming three groups.

Female genitalia (Fig. 11). Sterigma short with small lateroproximal parts; ductus bursae membranous, broad; corpus bursae elongate with one short and one large lateral sclerite extending to base of ductus bursae. 


\section{Type material}

Holotype male: "Mexico: Chia[pas], La Sepultura, 800 m, 11.VI.1997, V.O. BECKER Col.; Col BECKER 109731", GS 44 WZ. Paratypes, three identically labelled females, one with GS $45 \mathrm{WZ}$.

\section{Biology and distribution}

Nothing is known except for the above label data.

\section{Etymology}

The name refers to the type locality, La Sepultura.

\section{Teapeulia albicota sp. n.}

(Figs 7, 8, 17)

\section{Diagnosis}

In facies, $T$. albicota differs from its congeners by the lack of a dorsopostbasal forewing blotch and in the male genitalia by the distinct angle of the sacculus.

\section{Description}

Wing span $10 \mathrm{~mm}$. Head white, labial palpus tinged yellow-brown to middle laterally; thorax brownish grey, tegula brownish yellow. Forewing almost uniformly broad throughout; costa fairly straight; termen straight, moderately oblique. Ground colour brownish yellow with slight orange hue. Median fascia mostly rust, marked blackish at costa and dorsum; blackish dot at costa postmedially. Cilia concolorous with ground colour. Hindwing grey, cilia slightly paler.

Male genitalia (Figs 7, 8). Uncus moderately long, shorter than sacculus; socius fairly long, broad; gnathos simple, with arm slightly broadening terminally; distal fourth of valva tapering terminally; sacculus well developed, broadening distally, angulate; phallus broad, proportionally short; cornuti absent.

Female unknown.

\section{Type material}

Holotype male: „Brasil: M[ato]G[rosso], Chapada dos Guimaraes 800 m, 20. XI. 1994, V.O. BECKER Col; Col. BECKER 94156”; GS 263 WZ. 


\section{Etymology}

The name refers to the colouration of the head; Latin: albus - white and Greek: kotis head.

\section{Thypsaenia gen. n.}

Type species: Thypsaenia psaenythia sp. $\mathrm{n}$.

\section{Diagnosis}

The male genitalia of Thypsaenia are similar to Teapeulia, as they have a simple, long valva, sacculus, and a large socius; but Thypsaenia has a well-developed valval costa, slender, sclerotized transtilla and slender phallus. The type species of this genus has a monochrome brownish forewing, whereas Teapeulia has a distinct pattern with a well-developed dorsobasal blotch and median fascia.

\section{Description}

Forewing markings reduced to an ill-defined tornal spot or the ground colour is monochrome, finely strigulated.

Male genitalia. Uncus simple, slender; socius moderately large, drooping; arm of gnathos slender, terminal plate short; valva slender, tapering slightly terminad with well-developed, sclerotized costa and reduced dorsobasal part; sacculus short, broad postbasally with short basal part; transtilla slender, well sclerotized, submembranous medially; phallus fairly short, slender, expanding ventroterminally; coecum penis long; cornuti missing.

Female unknown.

\section{Biology and distribution}

Nothing is known of the biology except for the collection dates: late September. The type species is from Bahia, Brazil, and was collected at altitudes of $400-700 \mathrm{~m}$.

\section{Etymology}

The name is an anagram of the specific name of the type species.

\section{Remarks}

Thypsaenia shares some genital characters with Plesiocochylis RAZOWSKI \& WOJTUSIAK, 2008, a genus in Cochylini which has a well-developed gnathos with a long terminal plate but the latter differs chiefly by the lack of an uncus and the long basal part of the sacculus. 


\section{Thypsaenia psaenythia sp. $\mathbf{n}$.}

(Figs 9, 10, 18)

\section{Diagnosis}

T. psaenythia is the only species of the genus. In facies, it is somewhat similar to the Brazilian Terinebrica paulista RAZOWSKI \& BECKER, 2008.

\section{Description}

Wing span $15 \mathrm{~mm}$. Head rust brown, labial palpus browner; thorax mostly grey. Forewing moderately broad, beyond basal curvature of costa not expanding terminad; costa straight except for base, termen moderately oblique, almost straight. Ground colour brownish finely strigulated brown, tinged grey terminally; markings brown in form of a diffuse tornal spot or absent; cilia blackish brown. Hindwing brownish cream, cilia similar.

Male genitalia (Figs 9, 10) as in the description of the genus.

\section{Material examined}

Holotype male: "Brasil: Ba[hia], Camaca 400-700 m, 21-30. IX. 1991, V.O. BECKER Col.; Col. BECKER 84381"; GS 234 WZ. Paratypes, two identically labelled males, one with GS 213 WZ.

\section{Etymology}

The name refers to the facies of the moths; Greek: painythos - false.

\section{Proathorybia Razowski, 1999}

(Fig. 19)

Proathorybia RAZOWSKI, 1999, Polskie Pismo entomol., 68: 89 - replacement name for Athorybia RAZOWSKI, 1997.

Athorybia RAZOWSKI, 1997, Acta zool. cracov., 40: 80 - preoccupied. Type-species Athorybia athorybia RAZOWSKI, 1997.

\section{Redescription}

To the original description one can add the following data based on the male of $P$. zonalis RAZOWSKI \& BECKER, 2000 (Fig. 19). Shape of wings and markings as in Teapeulia with developed dorsopostbasal blotch. Large orange area with small orange and black scales edged by a slender fold in male hindwing. 
Base of uncus forming three, small rounded lobes; socii large, broad; arm of gnathos long, slender; terminal plate of latter long, slender; apart from ventrosubterminal spines there are two thorns on the sacculus dorsally; phallus broad; cornuti 3-5 long spines with laterosubterminal attachment points.

\section{Distribution}

P. zonalis was described from the state of Minas Gerais, Brazil, and the holotype was collected in late July at an altitude of $850 \mathrm{~m}$. Two additional specimens are from São Bento do Sul, Santa Catarina (29. VIII. 2000, leg. W. Mey, Berlin) and Chapada, Mato Grosso (7-8. IV. 1996, leg. V.O. BECKER, Col. BECKER 106672).

\section{Remarks}

The three species mentioned in this paper were originally described in Proathorybia; two of them can be transferred to Teapeulia and one to Sagittranstilla. The adult of $P$. zonalis is photographed (Fig. 19) for the first time.

\section{REFERENCES}

RAzOWSKI J. 2016. Diagnoses and remarks on the genera of Tortricidae (Lepidoptera). Part 4. Cnephasiini, Ceracini, Atteriini, Sparganothini and Euliini. Acta zoologica cracoviensia, 59 (2): 89- 151 .

Received: 16 April 2019

Accepted: 14 August 2019 